\title{
Climate change and religion: from ethics to sustainability action
}

\author{
Andi Luhur Prianto ${ }^{1,2^{*}}$, Achmad Nurmandi ${ }^{1}$, Zuly Qodir ${ }^{1}$, and Hasse Jubba ${ }^{1}$ \\ ${ }^{1}$ Doctorate Program of Political Islam-Political Science, Universitas Muhammadiyah Yogyakarta, \\ Indonesia \\ ${ }^{2}$ Department of Government Studies, Faculty of Social and Political Sciences, Universitas \\ Muhammadiyah Makassar, Indonesia
}

\begin{abstract}
This library research aims to: 1) explore the ethical aspects of the environment in climate change events, 2) map the moral values and philosophy of religion in climate change actions, 3) integrate the ethical, moral and philosophical aspects of religion by presenting new knowledge in sustainability actions. In this study, there are three concepts of environmental ethics, namely, the anthropocentric view, ecocentrism view, and religious, moral view. The anthropocentric view makes humans own and control natural resources exploitatively. The ecocentrism view places humans and the universe connected in a web of life. Moral religion sees problems born from human consciousness caused by sin and holiness. The way to solve the problems is to follow the "middle way," which advocates simplicity in consumption and the fulfillment of basic human needs. This approach builds a new order by combining the application of technology, law, and global ethics from an anthropocentric perspective - the ecocentrism view with everything having an intrinsic value. For example, the practice of intelligence and meditation uses religious, moral values for sustainable actions. Such as with the experience of various Islamic religion-based organizations in Indonesia.
\end{abstract}

\section{Introduction}

Humans in modern times are facing many severe and life-threatening environmental problems. One of them is the problem of disasters due to the impact of global climate change. The problem of climate change does not only occur naturally but is also caused by human activities. As observed by Gore [1], the cause of climate change is human activity. Natural forces do not cause global warming. Neither meteorite hits the earth nor does the earth move closer to the sun. Humans are the leading cause of damage problems on earth [2]. Since the beginning of the industrial revolution in England in the 17th century, coal, and later petroleum, has been used as fuel for scientific and technological advances that have made industrial factories emit increasingly large amounts of carbon dioxide. In addition, advances in automotive technology for transportation and logistics also release large amounts of carbon dioxide [2-3].

Human activities have led to a rapid increase in greenhouse gas emissions, impacting temperature changes over the last three decades. This is due to the attitudes and behavior of humans who lack awareness and ethical responsibility towards the environment, thus making the problem even more severe if no solution is found [2,5].

Most people view climate change as a matter of scientific knowledge without realizing the consequences that will befall humanity. Mostly they think that scientists and engineers

\footnotetext{
* Corresponding author: luhur@unismuh.ac.id
} 
to find a solution to the problem. However, this contradicts Gore's [1] thinking, which states, "... global warming is not only limited to scientific or political issues but also ethical issues for the environment". To consider this issue, the researcher uses the concept of environmental ethics as well as moral values and religious philosophy in analyzing three climate change issues: a) anthropocentric view: according to this concept, humans are separated from the unity of the universe. They dominate nature as the conquest of nature itself. Gustafson [6] observed that science and technology are tools to implement human rights to dominate nature to fulfill human pleasures and comforts, which are insatiable. This view encourages exploitation activities on natural resources; b) ecocentrism view: according to this concept, everything has its value. Everything is interdependent and bound together in a holistic relationship. Everything in the universe is sacred. Humans live with nature based on respect and humility. Humans do not separate themselves from objects and other people. Human identity is bound and indistinguishable from nature, as is found in the Native American philosophy of life, which held that "in the circle of life, there is no higher or lower life. We are siblings. Life is to share with birds, bears, insects, plants, mountains, clouds, stars, sun" [7]; c) morals of religion view: this concept focuses on seeing the world as it is. Humans relate to the environment. Viewing life holistically, all things in this universe depend on each other. The phenomena of the physical and non-physical world take place according to natural law.

The ethical principles in the morality of religions such as Buddhism and Islam teach humans to be sufficient in fulfilling the needs of human life. Spiritual achievement in finding satisfaction, practicing love, and seeing the value of nature and preserving nature. Religious, moral values like this direct to a sustainable harmony of human life and nature and a happy life with nature. This kind of praxis of life is seen in the life of forest monks in Thailand. In Islam, there are guidelines for life in interacting with the universe, such as QS. Ar-Rum: 41 reads, "damage has appeared on land and at sea due to the actions of human hands; Allah wants them to feel as a result of their actions, so that they return (to the right path)." The moral value of the verse will encourage Muslims to maintain sustainability and make repairs to the damage to the universe.

Anthropocentric, ecocentrism and religious moral views are identified and mapped in reviewing the role of religion in sustainability actions, which adapt to the threat of climate change. The concepts of environmental ethics can be integrated with the morals of religions in solving climate change problems. This research can be useful in finding solutions to the problem of climate change and integrating religious knowledge as the basis for sustainable development.

\section{Research Method}

This study uses a qualitative-exploratory method with a narrative-phenomenological approach. The research focus is climate change through the integration of environmental ethics and religious morals. This study aims to: 1) explore the ethical aspects of the environment in climate change events, 2) map the moral values of religion in climate change actions, 3 ) integrate the ethical and moral aspects of religion by presenting new forms of knowledge in sustainability actions. This study uses 3 (three) concepts of environmental ethics [2], namely, anthropocentric view, ecocentrism view, and religious, moral view. The study results were processed using a data processing application, namely Nvivo 12 Pro, and analyzed qualitatively.

\section{Result and Discussion}

\subsection{Transforming ethics into religious action in climate change adaptation}

Climate change results from human activities that change the composition of the Earth's atmosphere, either directly or indirectly. This condition is supported by the 
variability of natural weather conditions, including temperature, humidity, rainfall, and season. The threat of climate change is a global problem, where humanity must work together to prevent and improve its ability to adapt and deal with the impacts of changes that will occur [8-9]. At least there is concrete action to prevent the increase in the world's average temperature every year, not to exceed 2 degrees Celsius. According to Fulton [10], climate change is perhaps the greatest threat to global ecosystems that humanity has ever faced. In the current year 2019, it stands at 0.87 [2].

The impact of climate change due to global warming cannot be avoided-El Niño phenomena, tsunamis, melting of polar glaciers, storms, and more severe health problems. Everything affects the survival of humans and other creatures in the universe. However, there are many ways to solve the problem. Some focus on technology development, especially renewable energy sources, while others focus on international cooperation. The Kyoto Protocol is one of the international climate conventions that aim to stop the adverse effects of climate change by using a mechanism that allows the global community to help each other reduce the amount of greenhouse gas emissions. This global agreement also tries to invite developed country governments to ratify this protocol, using environmental laws or environmental standards [2,11-12].

So far, research on climate change is part of environmental ethics, which is more profound than environmental science or environmental law. It is generally found that the perception of environmental damage or the universe depends on the concept of human belief. In considering the impact of climate change, researchers will examine the issue using belief in facing the risks of climate change.

The following is an elaboration of the principles of environmental ethics that are related to religion and climate change, including the perspectives of Buddhism, Hinduism, Christianity, and Catholicism, as well as Islam:

Buddhist ethics: Ecological principles emerge from truth-seeking methods and behavior. Truth (Buddha) is having faith in the enlightenment of the Buddha. Ethical principles, including discipline, have value and meaning for Buddhist teachings that study and follow the Buddha's philosophy. As in 1) Buddhism teachings for monks for the conservation of aquatic plants, 2). The "middle way" in the ethical principles of Buddhism. 3) The practice of "practically triple" consists of precepts, concentration, and wisdom. Right speech, right livelihood, and right action are precepts. Proper understanding and right thought belong to the category of concentration, while right effort, right mindfulness, and right concentration are wisdom (Sammathitthi and Samaramkamppa) [2].

Hinduism ethics: A factor that plays a role in shaping the country's diet in India is Vrat, namely fasting. Fasting is generally defined as being willing to reduce or minimize the consumption of certain foods and beverages. The pinnacle of religiosity for a Hinduist shows a neglect of the fulfillment of worldly human needs and a focus on prayer and connection with the Divine. Fasting is a practice that exists in most religions around the world, and Hinduism is no exception. Therefore, we can see people fasting or praying almost every day throughout the year [13].

Christian and Catholic Ethics: The critical values identified in Christian and Catholic ethics are love, compassion, admiration, and respect for God's creation. This value is sometimes referred to as creation or stewardship care (Kearns 1996; DeWitt 1998). Love and respect for the earth are deeply embedded in secular environmental values. Nevertheless, what makes the difference in eco-theology is the view of the earth as part of God's creation and the belief that humans must take care of it. Connecting the earth explicitly with parts of God's creation reminds us of the core of spirituality (connection of all things), which can motivate [14].

Islamic ethics: Waqf plays a dramatic multi-dimensional socio-economic role in Islamic civilization concerning the improvement of the environment. Waqf finances not 
only expenses for mosques, including the salaries of imams and operational costs, but also educational institutions. However, the critical starting point of applying this waqf is a holistic world view that integrates religion and science into a single entity and hierarchy of knowledge. The goal is to have a spiritually meaningful impact that satisfies a spiritual and other needs [15].

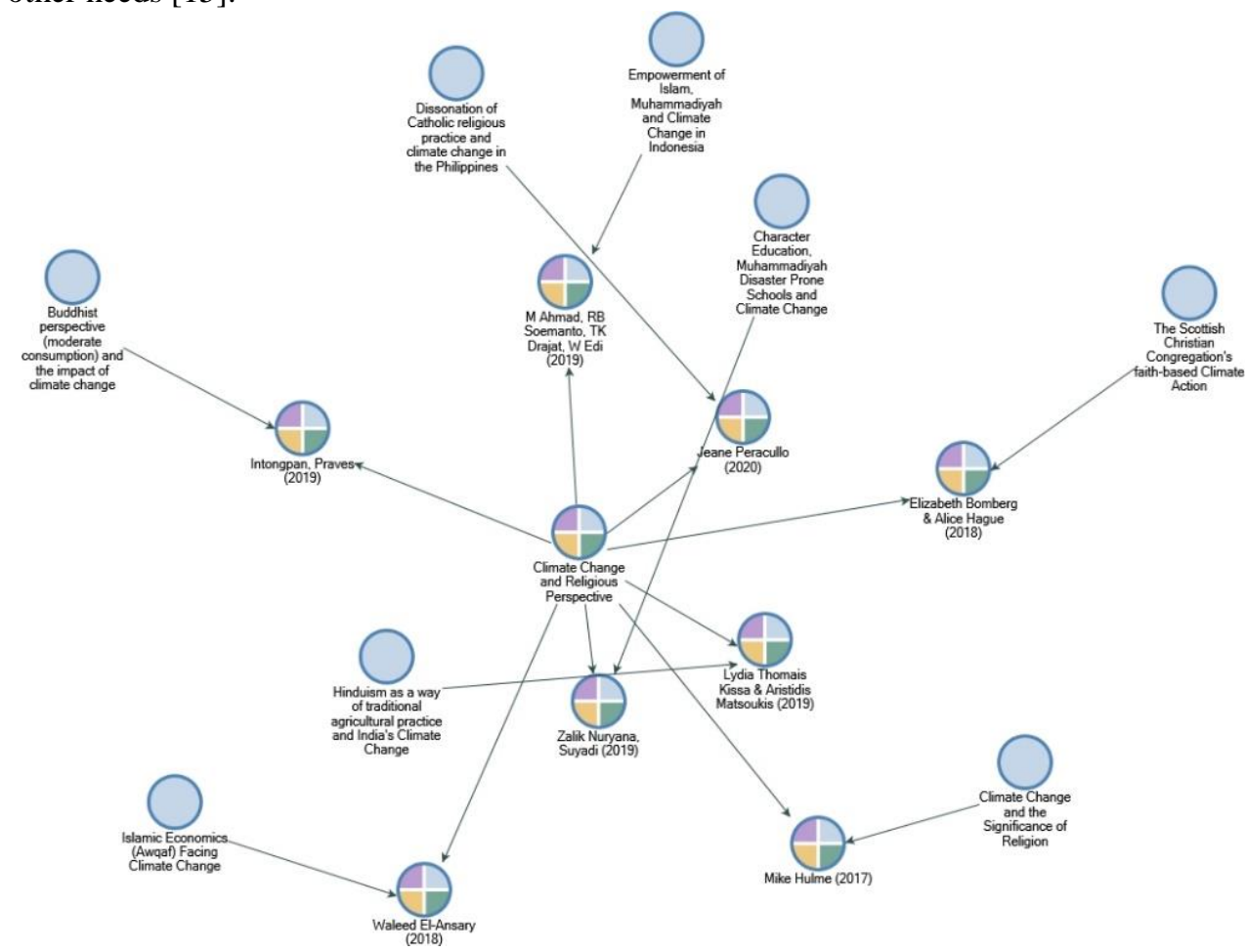

Fig.1. The relationship between religious morality and the impact of climate change

Figure 1 above shows how religions view the phenomenon of climate change. Based on previous research, the world's major religions have moral values in preventing climate change disasters and the implementation of teachings for sustainable actions. Islam sees climate change and the steps to overcome it. Meanwhile, Christians and Catholics see the catastrophe of climate change and the adaptation measures that can be taken. Hinduism understands the same thing in seeing the risks of the impact of climate change and its countermeasures, and Buddhism in seeing climate change disasters and strategies to deal with them. These religious aspects form a new environmental ethic that comes from religious ethics, which can benefit the world in general and Indonesia in particular. The following will explain more descriptively based on the grouping of religious perspectives and strategies to deal with the impacts of climate change. As in the following table:

Table 1. Perspectives of Religions \& Strategies for Facing Climate Change

\begin{tabular}{|c|l|}
\hline Religions & \multicolumn{1}{c|}{ Climate Change Action } \\
\hline \multirow{2}{*}{ Islam } & $\begin{array}{l}\text { - Character education in vulnerable schools. Islamic } \\
\text { organizations, such as the Muhammadiyah action, } \\
\text { deal with the impacts of climate change [16]. } \\
\text { - Community empowerment by Muhammadiyah as }\end{array}$ \\
\hline
\end{tabular}




\begin{tabular}{|c|l|}
\hline & $\begin{array}{l}\text { part of climate change adaptation in Indonesia [17]. } \\
\text { Improving the Islamic economy through the principle } \\
\text { of Waqf in the face of climate change [15]. }\end{array}$ \\
\hline Christian \& Catholic & $\begin{array}{l}\text { - The dissonance of Catholic religious practices and } \\
\text { climate change in the Philippines [18]. } \\
\text { Faith-based climate action Christian Congregations in } \\
\text { Scotland [14]. }\end{array}$ \\
\hline Hinduism & $\begin{array}{l}\text { Hinduism, as a way of traditional agricultural practice, } \\
\text { minimizes the risk of environmental damage and the } \\
\text { impact of climate change in India [13] }\end{array}$ \\
\hline Buddhist & $\begin{array}{l}\text { Buddhist perspective for moderate consumption and } \\
\text { modest attitude as an effort to face the risks of climate } \\
\text { change in Thailand [2] }\end{array}$ \\
\hline
\end{tabular}

\subsection{Learning from sustainability actions by Islamic-based organizations in Indonesia}

As the country with the largest Muslim population globally, it is essential to see how Islamic-based organizations in Indonesia carry out sustainable actions. Their work has contributed to climate change disaster mitigation and rehabilitation activities. Several scholars have examined the forms of environmental actions that faith-based organizations have carried out. As in the relationship map in the following picture:

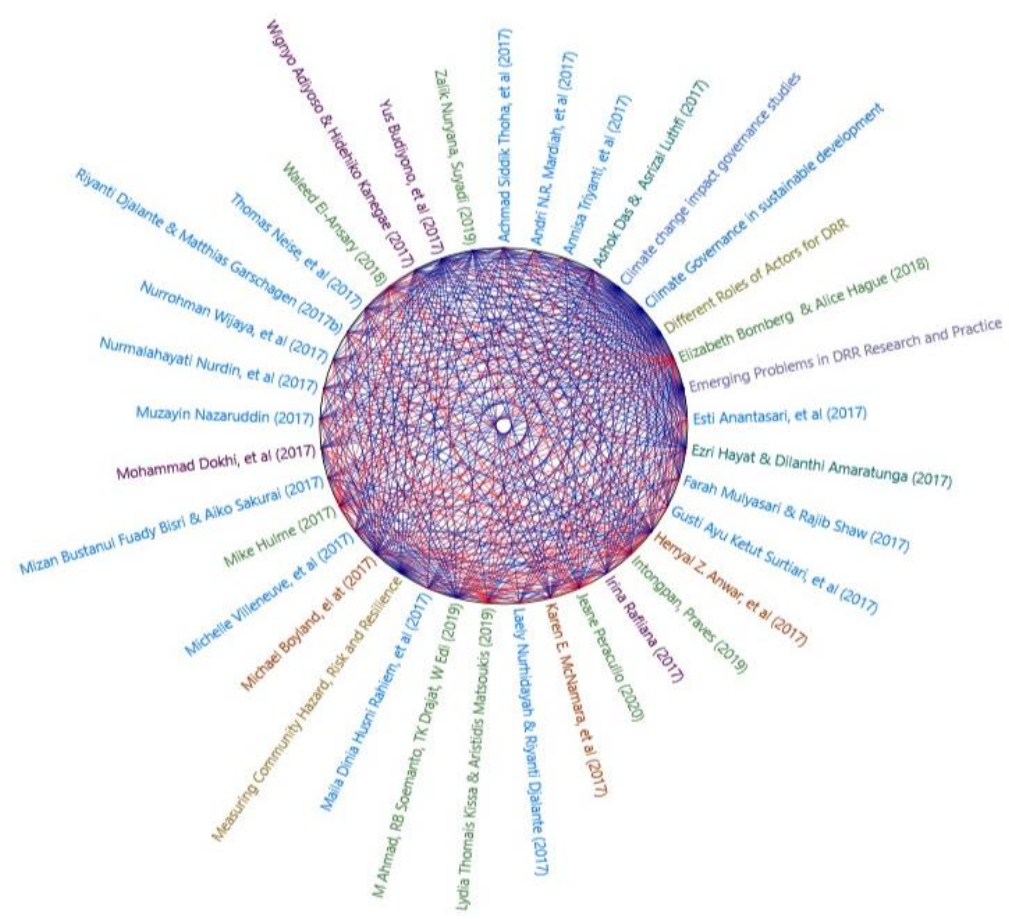

Fig.2. map of issues and relations of climate change activities by Islamic-based community organizations in Indonesia 
The picture above explains that there are two categories of previous research based on religion and climate change. In the climate change-based field, there are 4 (four) subcategories: First, the category of disaster risk management from the national to the regional level and its integration into the development sector in Indonesia. In this category, 8 studies have been studied, consisting of Andri et al [19]; Ashok et al [20]; Esti et al [21]; Laely et al [22]; Mizan et al [23]; Nurmalahayati et al [24]; Nurrohman et al [25]; \& Riyanti et al [26]. Second, the different categories of actor roles for disaster risk reduction (DRR) in Indonesia. In this second category, 8 studies have been studied, consisting of Ezri et al [27]; Farah et al [28]; Irina 29]; Karen et al [30]; Michael et al [31]; Michelle et al [32]; Muzayin [33]; Thomas [34]. Third, problems usually arise in research and practice in disaster risk reduction (DRR). In this category, three studies have been studied, consisting of Annisa et al [35]; Gusti et al.[36]; Maila et al.[37]. Fourth, the category of reducing hazards, risks, and community resilience in Indonesia. This category has been studied by 5 researchers, consisting of Achmad et al [38]; Herryal et al [39]; Dokhi et al [40]; Wignyo et al [41]; Budiyono et al [42].

Furthermore, in the second field of religious-based organizations in Indonesia, there are three studies that state that Muhammadiyah is a religious-social organization that is in the education movement. Muhammadiyah schools teach about threats, resilience, and adaptation to the impacts of climate change in Indonesia, the research consists of Ahmad et al. [17]; Hulme [43]; and Zalik et al. [16].

\section{Conclusion}

In the concept of environmental ethics and religious morals, it can be concluded that the anthropocentric view makes humans the center of life so that the universe exists to meet human needs. This perspective encourages humans to act exploitatively and destructively in managing natural resources. This behavior can be categorized as "acts of human hands" that cause damage to the earth as described in the teachings of Islam, Christianity, Hinduism, and Buddhism. In the ecocentric view, humanity and all creatures of nature are bound together in the web of life. Therefore, it relates to solving problems with the importance of ecological awareness. The moral value of religion sees environmental damage from the lack of human intelligence as the cause of "dirtiness" and advocates simplicity in fulfilling human needs. The integration of ethical and moral aspects of religion is proven to be transformed into sustainable actions. Such is the experience of various Islamic religionbased organizations in Indonesia.

\section{References}

1. A. Gore, An Inconvenient Truth, 3rd ed. (Matichon, Bangkok, 2007)

2. P. Intongpan, PSAKU Unternational J. Interdiscip. Res. 95 (2019)

3. T. Sriyakul, K. Jermsittiparsert, S. Phanwichit, and A. L. Prianto, Int. J. Innov. Creat. Chang. 8, 142 (2019)

4. E. Andrew, Introduction to Modern Climate Change (Cambridge University Press., New York, 2012)

5. T. Sriyakul, A. L. Prianto, and K. Jermsittiparsert, Humanit. Soc. Sci. Rev. 7, 695 (2019)

6. J. Gustafson, God, Nature and Human in the Western Religious Traditions. " In Man and Nature: A Cross- Culture Perspective (Chulalongkorn University, Bangkok, 1993)

7. G. Session, JKAU Islam. Econ. 31, 79 (1995)

8. A. L. Prianto and A. A. Amalia, Otoritas J. Ilmu Pemerintah. 9, 28 (2019) 
9. I. Malik, A. L. Prianto, A. Abdillah, Z. Rusnaedy, and A. A. Amalia, J. Gov. Civ. Soc.

5, $31(2021)$

10. J. Fulton, Ecosyst. Heal. 5, 110 (2001)

11. A. L. Prianto, 1, 1 (2011)

12. N. Faisah and A. L. Prianto, Otoritas J. Ilmu Pemerintah. 5, 74 (2015)

13. L. T. Kissa and A. Matsoukis, Int. Sci. Surv. J. 2, 1 (2019)

14. E. Bomberg and A. Hague, Local Environ. 23, 582 (2018)

15. W. El-Ansary, J. King Abdulaziz Univ. Islam. Econ. 31, 79 (2018)

16. Z. Nuryana and S. Suyadi, J. Educ. Learn. 13, 219 (2019)

17. M. Ahmad, R. B. Soemanto, T. K. Drajat, and W. Edi, IOP Conf. Ser. Earth Environ. Sci. 356, 1 (2019)

18. J. Peracullo, Religions 11, 1 (2020)

19. Andri N.R. Mardiah, J. C. Lovett, and N. Evanty, in Disaster Risk Reduct. Indones. Progress, Challenges, Issues (Springer International Publishing AG, Switzerland, 2017), pp. 57-84

20. A. Das and A. Luthfi, in Disaster Risk Reduct. Indones. Progress, Challenges, Issues (Springer International Publishing AG, Switzerland, 2017), pp. 85-126

21. Esti Anantasari, M. Daly, P. Glassey, E. Grace, M. Coomer, and R. Woods, in Disaster Risk Reduct. Indones. Progress, Challenges, Issues (Springer International Publishing AG, Switzerland, 2017), pp. 127-156

22. L. N. and R. Djalante, in Disaster Risk Reduct. Indones. Progress, Challenges, Issues (Springer International Publishing AG, Switzerland, 2017), pp. 157-188

23. M. B. F. Bisri and A. Sakurai, in Disaster Risk Reduct. Indones. Progress, Challenges, Issues (Springer International Publishing AG, Switzerland, 2017), pp. 189-212

24. N. Nurdin, I. Rafliana, S. Hidayati, R. S. Oktari, and R. Djalante, in Disaster Risk Reduct. Indones. Progress, Challenges, Issues (Springer International Publishing AG, Switzerland, 2017), pp. 213-234

25. N. Wijaya, M. B. F. Bisri, A. F. Aritenang, and A. Mariany, in Disaster Risk Reduct. Indones. Progress, Challenges, Issues (Springer International Publishing AG, Switzerland, 2017), pp. 235-254

26. Riyanti_Djalante, Matthias_Garschagen, Frank_Thomalla, and Rajib_Shaw, Disaster Risk Reduction in Indonesia: Progress, Challenges, and Issues (Springer International Publishing AG, Switzerland, 2017)

27. E. Hayat and D. Amaratunga, in Disaster Risk Reduct. Indones. Progress, Challenges, Issues (Springer International Publishing AG, Switzerland, 2017), pp. 255-280

28. F. Mulyasari and R. Shaw, in Disaster Risk Reduct. Indones. Progress, Challenges, Issues (Springer International Publishing AG, Switzerland, 2017), pp. 377-394

29. I. Rafliana, in Disaster Risk Reduct. Indones. Progress, Challenges, Issues (Springer International Publishing AG, Switzerland, 2017), pp. 411-444

30. Karen E. McNamara, R. Clissold, J. Pearson, D. M.- Robertson, A. Ward, and L. Allgood, in Disaster Risk Reduct. Indones. Progress, Challenges, Issues (Springer International Publishing AG, Switzerland, 2017), pp. 395-410

31. M. Boyland, A. Nugroho, and F. Thomalla, in Disaster Risk Reduct. Indones. Progress, Challenges, Issues (Springer International Publishing AG, Switzerland, 2017), pp. 357-376

32. Michelle Villeneuve, A. Robinson, P. P. Pertiwi, S. Kilham, and G. Llewellyn, in Disaster Risk Reduct. Indones. Progress, Challenges, Issues (Springer International Publishing AG, Switzerland, 2017), pp. 335-356

33. M. Nazaruddin, in Disaster Risk Reduct. Indones. Progress, Challenges, Issues (Springer International Publishing AG, Switzerland, 2017), pp. 307-334

34. T. Neise, J. R. Diez, M. Garschagen, R. Djalante, K. Novianti, and C. N. Syahid, in 
Disaster Risk Reduct. Indones. Progress, Challenges, Issues (Springer International Publishing AG, Switzerland, 2017), pp. 281-306

35. A. Triyanti, Y. Walz, M. A. Marfai, F. Renaud, and R. Djalante, in Disaster Risk Reduct. Indones. Progress, Challenges, Issues (Springer International Publishing AG, Switzerland, 2017), pp. 445-468

36. G. A. K. Surtiari, R. Djalante, N. J. Setiadi, and M. Garschagen, in Disaster Risk Reduct. Indones. Progress, Challenges, Issues (Springer International Publishing AG, Switzerland, 2017), pp. 469-494

37. M. D. H. Rahiem, N. S. M. Abdullah, and S. E. Krauss, in Disaster Risk Reduct. Indones. Progress, Challenges, Issues (Springer International Publishing AG, Switzerland, 2017), pp. 495-516

38. A. S. Thoha, B. H. Saharjo, R. Boer, and M. Ardiansyah, in Disaster Risk Reduct. Indones. Progress, Challenges, Issues (Springer International Publishing AG, Switzerland, 2017), pp. 539-560

39. Herryal Z. Anwar, E. Yustiningrum, N. Andriana, D. T. P. Kusumawardhani, S. Sagala, and A. M. Sari, in Disaster Risk Reduct. Indones. Progress, Challenges, Issues (Springer International Publishing AG, Switzerland, 2017), pp. 609-620

40. M. Dokhi, T. H. Siagian, A. P. Utomo, and E. Rumanitha, in Disaster Risk Reduct. Indones. Progress, Challenges, Issues (Springer International Publishing AG, Switzerland, 2017), pp. 589-608

41. W. Adiyoso and H. Kanegae, in Disaster Risk Reduct. Indones. Progress, Challenges, Issues (Springer International Publishing AG, Switzerland, 2017), pp. 561-588

42. Y. Budiyono, M. A. Marfai, H. de M. Jeroen Aerts, and P. J. Ward, in Disaster Risk Reduct. Indones. Progress, Challenges, Issues (Springer International Publishing AG, Switzerland, 2017), pp. 517-538

43. M. Hulme, Comment. Econ. Polit. 4 (2017) 